\title{
Linear SRY Transcript in Equine Testis
}

Telhisa HASEGAWA, Michiyo ISHIDA ${ }^{1)}$, Toshio HARIGAYA ${ }^{1)}$, Fumio SATO, Nobushige ISHIDA and Harutaka MUKOYAMA

Laboratory of Molecular and Cellular Biology, Equine Research Institute, Japan Racing Association, Utsunomiya 320-0856, and ${ }^{1)}$ Laboratory of Functional Anatomy, Faculty of Agriculture, Meiji University, Kawasaki 214-0033, Japan

(Received 13 July 1998/Accepted 3 September 1998)

ABSTRACT. Employing a combination of reverse transcription-polymerase chain reaction (RT-PCR) and rapid amplification of cDNA ends (RACE) techniques, the complete coding sequence of cDNA for the equine $S R Y$ gene was determined. We also attempted to make clear whether the equine $S R Y$ gene transcript is expressed in the adult testis, and whether the type of transcript is expressed as linear or circular RNA. As a result, in total a 1420 bp cDNA sequence was determined. Accomplishment of 3' RACE infers that equine $S R Y$ gene was expressed as a linear RNA transcript in testicular tissue just after puberty, in contrast to the situation in mice.- KEY wORDS: equine, sexdetermination, $S R Y$.

The function of $S R Y$ gene in inducing male gonadal differentiation was identified by development of a XX transgenic mouse with testes by introducing a single gene into an embryo [11]. The intron-less $S R Y$ encodes a putative transcriptional protein harboring the HMG motif [1, 17]. The HMG motif is highly conserved despite lesser conservation in other domains [4]. Therefore, the HMG motif must play a critical role in the transcriptional regulation leading to the development of male gonads $[6$, 10]. However, a non HMG box C-terminal domain of $S R Y$ protein may also be indispensable for inducing normal testicular development [9]. As with other domestic animals, the inquiry into genetic diagnosis for infertility is increasing in equine clinics. PCR amplification of the SRY gene will provide a more powerful tool in addition to karyotyping [12]. Although generic primers are commonly used for this purpose, the generic primers cannot eliminate the possibility of amplifying a contaminating human counterpart. Moreover, since the HMG-box is a common structure for high mobility gene group proteins, many homologues, such as members of the SOX family, are cloned by screening genomic libraries with a $S R Y$ HMG-box probe [4]. Consequently, molecular cloning of equine $S R Y$ gene is requisite to both specific diagnoses in reproductive disorders and functional analysis of gonadal differentiation in equids. We report the first cloning of equine $S R Y$ gene transcript expressed in the adult testicular tissue by a combination of RT-PCR and rapid amplification of cDNA ends (RACE) techniques, instead of screening an equine genomic DNA library. Employing 3' RACE technique as a method of cDNA cloning, we also attempted to investigate whether the form of the equine testicular $S R Y$ transcript is linear or not.

Testicular tissue obtained from a thoroughbred colt $(2$ years old) by castration was diced into $10 \mathrm{~mm}$ cubes, and quickly frozen in liquid nitrogen. Frozen testicular tissue was stored at $-80^{\circ} \mathrm{C}$ until RNA extraction. Total testicular RNA was extracted by guanidinium/cesium chloride ultracentrifugation [2]. Poly $(\mathrm{A})^{+}$rich RNA was purified with OligoTex dT30 SUPER (Takara, Kyoto). Double stranded cDNA of equine testis was synthesized from poly $(\mathrm{A})^{+}$rich RNA with SuperScript Choice System for cDNA Synthesis (GIBCO BRL, Bethesda) using poly(dT) primer. A pair of oligonucleotide primers ESRY-R25E and ESRY-F23E were designed by comparing equine $[8,12]$ and human [17] $S R Y$ consensus sequences, and the hypothetical size of the amplification product was $195 \mathrm{bp}$. In $200 \mu l$ MicroAmp tubes (Perkin-Elmer, Urayasu), 100 pmoles of each primer, 400 nmoles of each dNTP, 10 to 30 ng of equine testicular cDNA as template, and 2.5 units of Taq PLUS DNA polymerase (Stratagene, San Diego) were mixed in $100 \mu l$ low salt reaction buffer (provided with Taq PLUS DNA polymerase; Stratagene, San Diego) reaction mixture. Thermal cycling parameters consisted of a preamplification denaturation at $94^{\circ} \mathrm{C}$ for $5 \mathrm{~min}$ followed by 60 shuttle thermo-cycles of $94^{\circ} \mathrm{C}$ for $30 \mathrm{sec}$ and $55^{\circ} \mathrm{C}$ for $30 \mathrm{sec}$, and extension at $72^{\circ} \mathrm{C}$ for $7 \mathrm{~min}$ [15]. The $S R Y$ conserved region was successfully amplified as an expected size fragment from equine testicular cDNA (Fig. 1, Lane 1). PCR products were analyzed by agarose gel electrophoreses and purified with GENE CLEAN II kit (BIO-101, La Jolla). Purified PCR fragments were ligated with pGEM-T Easy Vector (Promega, Madison) and transformed E. coli cells (XL-1 Blue MRF'; Stratagene, San Diego). An A.L.F. automated sequencer (Pharmacia Biotech, Tokyo), fluorescein labeled sequence primers (M4 and RV-M; Takara, Kyoto), and SequiTherm Long-Read Cycle Sequencing Kit (Epicentre Technologies, Madison) were used for the determination of nucleotide sequences [16]. The PCR product was $195 \mathrm{bp}$ in sequence, and identical to the previously reported partial equine $S R Y$ genomic sequences $[8,12]$. Three antisense strand primers, R1-SRY R3-SRY and R4-SRY, for 5' RACE and 2 sense strand primers, F1-SRY and F3-SRY for 3' RACE (Table 1) were designed from the sequence of PCR product of the SRY consensus region. 5' RACE System version 2.0 (GIBCO BRL, Bethesda) and 3' RACE Adapter Primer (GIBCO BRL, Bethesda) were used for rapid amplification of both cDNA ends [7, 13]. RACE procedures were performed according to the manufacturer's instructions, using 1 to 2 


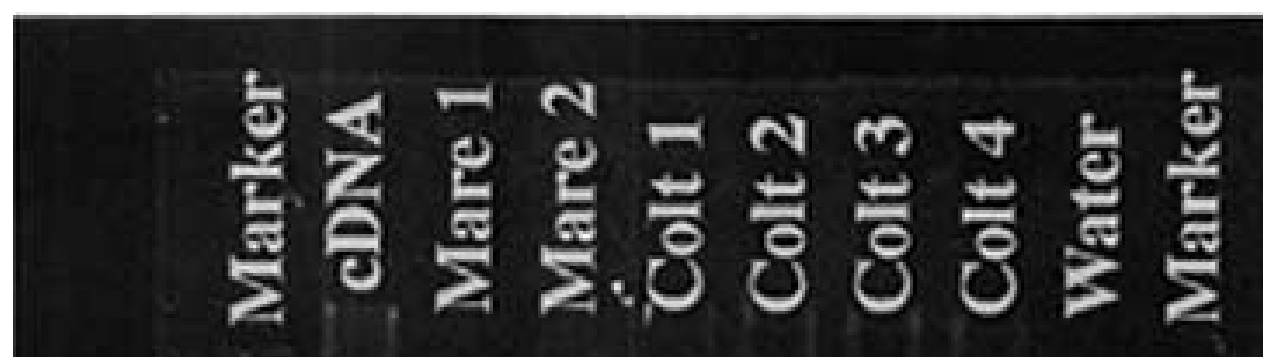

\section{$500 \mathrm{bp}$ \\ $200 \mathrm{bp}$}
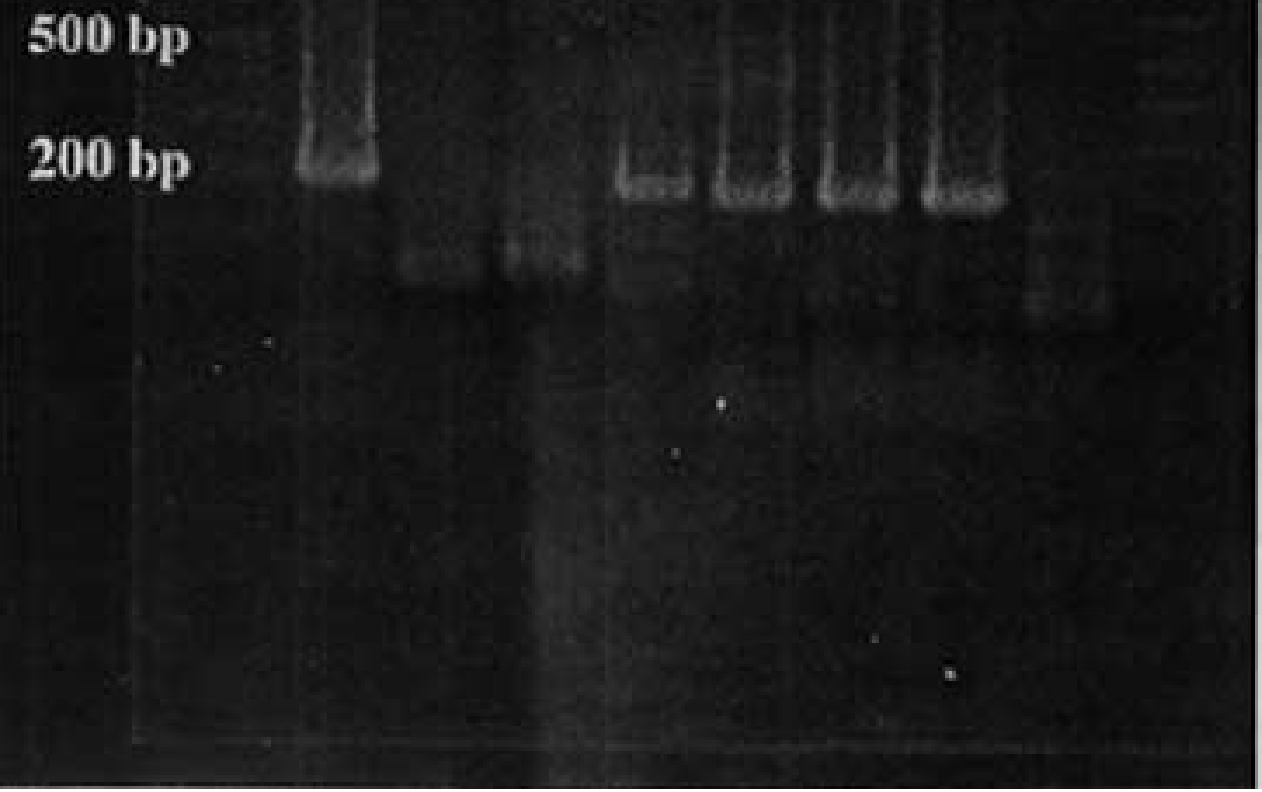

Fig. 1. PCR products from equine testicular cDNA and genomic DNA. HMG box (195 bp) fragments were amplified from testicular cDNA (cDNA) and male genomic DNA (Colt 1-4), but not amplified from female genomic DNA (Mare 1-2) and negative control (Water).

Table 1. Oligodeoxynucleotide primers used in this study

\begin{tabular}{ll}
\hline \multicolumn{1}{c}{ Primers } & \multicolumn{1}{c}{ Sequences $\left(5^{\prime}-3^{\prime}\right)$} \\
\hline ESRY-R25E & GAATTCGGGTATTTCTCTTGATGCATAGCC \\
ESRY-F23E & ACCCATGAATTCATTCATGGTGTGGTCTCGTGA \\
poly(dT)AP* & GGCCACGCGTCGACTAC(T) ${ }_{17}$ \\
AAP* & GGCCACGCGTCGACTAGTACGGGIIGGGIIGGGIIG \\
AUAP* & GGCCACGCGTCGACTAGTAC \\
R1-SRY & CCTCAAAGAATGGCAATTTTCGGCTTCCG \\
R3-SRY & CGCTTGCTGATCTCTGAGTTTTGCAGTTGG \\
R4-SRY & GGGATTCTCTAGAGCGACCTTGCGCCTGTGA \\
F3-SRY & GAGAATCCCCAACTGCAAAACTCAGAGA \\
F5-SRY & AATTGCCATTCTTTGAGGAGGCACAGAG \\
\hline
\end{tabular}

*: Primers provided with RACE System (GIBCO BRL, Bethesda).

$\mu \mathrm{g}$ of total RNA or $100 \mathrm{ng}$ of poly(A) ${ }^{+}$RNA as templates.

Amplification products from 3' and 5' RACE procedures were successfully cloned, and sequenced. The product from 3' RACE was 1074 bp in length, and contained a putative poly-adenylation signal "AATAAA" at 19 bases upstream of the $17 \mathrm{nt}$ stretch of the poly(A) tail. The product from 5, RACE was 330 bases in length, and contained 99 bases of
5' untranslated region upstream of a putative $S R Y$ open reading frame. An in total 1403 bp cDNA sequence of equine testicular $S R Y$ transcript was reassembled from three fragments (one RT-PCR and two RACEs) of equine testicular cDNA harboring a $672 \mathrm{bp}$ (nucleotides 100 to 771) open reading frame encoding 223 amino acids of the presumed equine sex-determining protein. Both nucleotide 


\section{N-Terminal Region}

\begin{tabular}{|c|c|c|c|c|c|c|}
\hline & 10 & 20 & 30 & 40 & 50 & 7 \\
\hline & SRV & $S \perp A$ & U. & WTSNP & GSHFRSETRG & \\
\hline & SAMLS & VENSDDYSPA & ENIPALRR & SSSFLCTESC & NSKYQCETGE & NSKGNVQ \\
\hline & . MFRV & LNDDVYSPAV & VQQQTTLAFR & KDSSLCTDSH & SANDQCERGE & HVRESSQ \\
\hline & & & & & & . \\
\hline
\end{tabular}

\section{HMG (High Mobility Group) Domain}

\begin{tabular}{|c|c|c|c|c|c|c|c|c|c|c|c|c|c|c|c|c|c|c|}
\hline & 60 & 70 & & 80 & & 90 & & & 100 & & 110 & & & 120 & & & 130 & 13 \\
\hline & DRV & KRPMNAFMVW & SRDHRR & KVAL & ENPQLQN & NSEI & SKRLC & & VKM & LTEA & ELLPFF & & $\mathrm{QRLI}$ & RAMH & QEK & PDY: & KYR & \\
\hline & & I & $\mathrm{Q}$ & M & RMR & & $Q$ & $\mathrm{Y}$ & & & w & $Q$ & K & & $\mathrm{R}$ & $\mathrm{N}$ & & \\
\hline & $\mathrm{H}$ & I & ER & & KMK & D & $Q$ & YE & $\mathrm{F}$ & 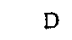 & $\mathrm{R}$ & & & L I & RD & G & & \\
\hline & $\mathrm{GH}$ & & $\mathrm{GE}$ & I L & SM & $\mathrm{T}$ & $Q$ & $\mathrm{CR}$ & $\mathrm{s}$ & & $\mathrm{R}$ & $Q$ & $\mathrm{R}$ & KIL & $\mathrm{R}$ & $\mathrm{N}$ & Q & $\mathrm{H}$ \\
\hline
\end{tabular}

\section{C-Terminal Region}

\begin{tabular}{|c|c|c|c|c|c|c|c|c|c|c|c|}
\hline & 140 & & 150 & & 160 & 170 & 180 & 190 & 200 & & 210 \\
\hline horse & MPQK & SDKPLP & PQTPL & LHCAGR & RRTYT & STSGCPFLIH & GRLFLRATQS & QTGGAVKPFA & AGATAISALQ & QELSQQHI & RTL \\
\hline human & MLPK & NCSLLP & PADPA & SVLCSE & EVQLD & NRLYRDDCTK & ATHSRMEHQL & GHLPPINAAS & SPQQRDRYSH & WTKL* & \\
\hline cattle & RPQK & SLPADS & SSILC & NPMHVE & ETLHP & FTYRDGCAKT & TYSQMESQLS & RSQSVIITNS & LLQKEHHSSW & TSLGHNKT & VTL \\
\hline \multirow[t]{2}{*}{ mouse } & VSQR & SGILQP & PAVAS & TKLYNL & LLQWD & RNPHAITYRQ & DWSRAAHLYS & KNQQSFYWQP & VDIPTGHLQQ & QQQQQQQQ & $20 F$ \\
\hline & & 220 & & 230 & & 240 & 250 & 260 & 270 & 280 & \\
\hline horse & RCHSC & GNVGYA & DIRRR & RSLSL * & & & & & & & \\
\hline cattle & ATRIS & SADFPC & NKSLE & EPGLSC & AYFQY & & & & & & \\
\hline mouse & HNHHC & $20000 \mathrm{~F}$ & YDHHC & 200000 & 20006 & QQFHDH HQQ & QQFHDH HQQQQ & QQFHDH HHHHQ & EQQFH DHHQQ & $20 Q Q F H$ & \\
\hline \multirow[t]{3}{*}{ mouse } & DHQQS & $2 Q Q Q Q Q$ & QQQFH & ADHHQQ & KQOFH & HDHHHH QQQQ & QFHDHQ QQQQQ & QFHDHQ QQQHQ & FQQFH DHHQQ & $2000 \mathrm{FH}$ & 350 \\
\hline & HDHPS & $20 \mathrm{KQQF}$ & HDHPQ & $20 Q Q Q F$ & HDHHT & HQQQQK QQFH & DHHQQK QQFHD & DHHQQR DHHQQ & $20 Q Q 0 Q \quad 000 Q 0$ & QQFHDQ & 420 \\
\hline & & LLTADI & & QEEH & & & & & & & \\
\hline
\end{tabular}

Fig. 2. Comparison of deduced amino acid sequences for the SRY protein in equine, human, bovine and mouse species. Numbering is based on the human sequence. The depicted SRY sequence is divided into the N-terminal region, the HMG box and the C-terminal region. Only nonhomologous sequences for the HMG domain are shown. Stop codons are represented by *.

and amino acid sequences of reconstructed equine $S R Y$ transcript were compared with the registered data of GenBank and SWISSPROT databases by personal computer based sequence analyzing software (DNASIS-Mac; Hitachi Software, Yokohama). The nucleotide sequence of equine $S R Y$ transcript, which will appear in the DDBJ, EMBL and NCBI nucleotide sequence databases with the accession number AB004572, and its predicted amino acid sequence were highly conserved in the HMG motif, while sequence similarities with human and cattle were less consistent in other parts of the sequence (Fig. 2, Table 2).

Accomplishment of 3' RACE, the existence of a putative poly-adenylation signal and the $17 \mathrm{nt}$ stretch of the poly(A) tail suggest that the equine $S R Y$ gene was expressed as a linear RNA transcript in testicular tissue at puberty. In cattle, the $S R Y$ gene transcribed in mature, but not late fetal or adolescent, bull testicle could be cloned by 3' RACE [3]. On the other hand, linear Sry transcripts of mice are detected only in the genital ridge of the early embryo, and the major form of Sry transcript is a circular RNA in the
Table 2. Nucleic acid and amino acid similarity (\%) of N-terminal, HMG-box and C-terminal regions of equine $S R Y$ to human, bovine and mouse $S R Y / S r y$ sequences*

\begin{tabular}{cccc}
\hline & \multicolumn{3}{c}{ Region } \\
\cline { 2 - 4 } & N-terminal & HMG-box & C-terminal \\
\hline Nucleic acid similarities / Overlap: & & \\
Human & $67.5 \% / 156$ & $86.5 \% / 237$ & $49.7 \% / 143$ \\
Cattle & $67.3 \% / 154$ & $84.0 \% / 237$ & $62.4 \% / 263$ \\
Mouse & $-\% * *$ & $78.0 \% / 236$ & $49.1 \% / 110$ \\
Amino acid similarities / Overlap: & & \\
Human & $39.2 \% / 52$ & $82.3 \% / 79$ & $0 \%$ \\
Bovine & $38.5 \% / 52$ & $74.7 \% / 79$ & $0 \%$ \\
Mouse & $-\% * *$ & $69.6 \% / 79$ & $0 \%$ \\
\hline
\end{tabular}

*A homology search was performed using DNASIS-Mac ver.3.6 (Hitachi Software, Yokohama), utilizing a Lipman and Pearson search algorithm [14].

**Mouse $\mathrm{N}$-terminal sequences were too short to compare with equine sequences. 
differentiated testis [5]. The function of both types of testicular transcripts, circular Sry in mice and linear $S R Y$ in other species, are still under investigation. In this study, we demonstrate direct evidence for the linear messenger RNAtype $S R Y$ transcript in the equine differentiated testicle as well as its nucleotide sequence for the complete amino acid coding region. Lesser sequence consistency with other species in the non-HMG-box may contribute to species specific design of diagnostic primers.

\section{REFERENCES}

1. Bianchi, M.E., Falciola, L., Ferrari, S. and Lilley, D.M.J. 1992. ЕМВО J. 11: 1055-1063.

2. Chirgwin, J.M., Przybyla, A.E., MacDonald, R.J. and Rutter, W.J. 1979. Biochemistry 18: 5294-5299.

3. Daneau, I., Houde, A., Ethier, J.-F., Lussier, J.G. and Silversides, D.W. 1995. Biol. Reprod. 52: 591-599.

4. Denny, P., Swift, S., Connor, F. and Ashworth, A. 1992. EMBO J. 11: 3705-3712.

5. Dolci, S., Grimaldi, P., Geremia, R., Pesce, M. and Rossi, P. 1997. Biol. Reprod. 57: 1128-1135.

6. Ferrari, S., Harley, V.R., Pontiggia, A., Goodfellow, P.N., Lovell-Badge, R. and Bianchi, M.E. 1992. EMBO J. 11: 44974506.
7. Frohman, M.A. 1993. Methods Enzymol. 218: 340-356.

8. Griffiths, R. and Tiwari, B. 1993. Mol. Ecol. 2: 405-406.

9. Haqq, C.M., King, C.-Y., Ukiyama, E., Falsafi, S., Haqq, T.N., Donahoe, P.K. and Weiss, M.A. 1994. Science 266: 1494-1500.

10. Harley, V.R., Jackson, D.I., Hextall, P.J., Hawkins, J.R., Berkivitz, G.D., Sockanathan, S., Lovell-Badge, R. and Goodfellow, P.N. 1992. Science 255: 453-456.

11. Koopman, P., Gubbay, J., Vivian, N., Goodfellow, P. and Lovell-Badge, R. 1991. Nature (Lond.) 351: 117-121.

12. Meyers-Wallen, V.N., Hurtgen, J., Schlafer, D., Tulleners, E., Cleland, W.R., Ruth, G.R. and Acland, G.M. 1997. Equine Vet. J. 29: 404-408.

13. Ohara, O., Dorit, R.L. and Gilbert, W. 1989. Proc. Natl. Acad. Sci. U.S.A. 86: 5673-5677.

14. Pearson, W. R. and Lipman, D. J. 1988. Proc. Natl. Acad. Sci. U.S.A. 85: 2444-2448.

15. Saiki, R. K., Scharf, S., Faloona, F., Mullis, K. B., Horn, G. T., Erlich, H. A. and Arnheim, N. 1985. Science 230: 13501354.

16. Sanger, F., Nicklen, S. and Coulson, A. R. 1989. Proc. Natl. Acad. Sci. U.S.A. 74: 5463-5467.

17. Sinclair, A.H., Berta, P., Palmer, M.S., Hawkins, J.R., Griffiths, B.L., Smith, M.J., Foster, J.W., Frischauf, A.-M. Lovell-Badge, R. and Goodfellow, P.N. 1990. Nature (Lond.) 346: 240-245. 